\title{
Research Trend of Image-Based Biomechanical Simulation
}

\author{
Nobuhiro YOSHIKAWA*5, Taiji ADACHI, Marie OHSHIMA, \\ Katsuyuki SUZUKI and Takami YAMAGUCHI \\ ${ }^{* 5}$ Institute of Industrial Science. The University of Tokyo, \\ 461 Komaba Meguro-ku, Tokyo, 153-8505 Japan
}

Key Words : Biomechanics, Computational Mechanics, Bio-fluid Mechanics, Image Processing, Finite Element Method

\section{1.はじめに}

生体に特有の機能的な適応現象や生理的な過程を理 解し，それを医工学分野におけるデバイスの開発や診 断・治療技術に応用する場合, 生体と力学的な環境と の相互作用を理解することが重要となる．生体内で生 じる力学現象は, 生体のもつ構造の三次元性や階層性 により非常に複雑であり, 従来の計算力学的手法をそ のまま適用するだけでは不十分である。そこで、計算 機シミュレーションを援用した生体内現象解明のため の新たな技術として, 生体組織・構造のイメージベー ストモデリング技術，抢よび固体-流体の力学と生体 現象とが連成する複雑現象の解析技術が不可欠とな る.

計算力学におけるイメージベーストモデリングは, もともとバイオメカニクス分野において必要とされ， 各種の手法が開発されてきたが，医用画像のために開 発されてきた画像取得装置が工業目的に応用されるよ うになって，新たな展望がひらけてきた，医用画像は， 医用技術が工学技術をりードし，発想と開発の原点と なっている数少ない技術分野の一つであり，画像に基 ブくモデリングも広い意味でその一部である.一方, 連成解析は，狭義の流体一固体連成ばかりでなく，生体 を構成する広範な物理・化学現象を連成して解析しな

$*$ 原稿受付 2003 年 11 月 20 日.

*1 正員, 東京大学生産技術研究所( $\mathbb{E} 153-8505$ 東京都目黒区 駒場 4-6-1).

*22 正員, 神戸大I.学部(画657-8501 神戸书灘区六甲台町 1-1).

*3 正員. 東京大学新領域創成科学研究科( 113-8565 東京都 文京区本郷 7-3-1).

*4 正員, 東北大学工学研究科(-980)-8579 仙台市青葉区荒巻 字青葉 1).

E-mail : yoshi $a$ telu.iis.u-tokyo.ac.jp
い限り生命の秘密を解き明かし, 有用な技術的応用の 展望を切り開くことができないという意味で, 生命体 の科学技術の根本的な特徴と深く関わっている.さら に, バイオメカニクスは, たんに工学技術を生体問題 に応用するという段階から, 生命現象そのものの多物 理, 多重スケールの問題を通じて, 工学技術そのもの を考え直すという契機も与えるものと認識されつつあ る。本稿では, 医用画像診断装置と, そこから得られ た画像よりシミュレーションに必要な三次元幾何モデ ルを生成する手法, それに引き続き行われるバイオメ カニカルシミュレーションについて, 現状と展望を述 べる.また, 画像診断装置とシミュレーションを相補 的に用いる, シミュレーションインテグレイテッドイ ンスペクションとでも呼ぶべき新たな展開についても 解説する.

\section{2. 画像診断装置}

超音波診断装置, X 線診断装置, MRI (Magnetic Resonance Imaging)装置は, 画像情報を提供する代 表的医療診断装置である。それら 3 種とも, これまで の技術開発の目標は, 三次元画像を高解像度で短時間 に得ることであった. そのための計測機器自体の高精 度化はもちろんであるが, 1990 年代以降のデジタルイ メージ技術の発展が, これらの診断装置の価值を大い に高めることとなった。計算機能力の向上が, イメー ジ処理技術の高度化を誘発し, 画像情報をさらに豊富 にするために, 計測器ハードウエアの開発が推進され た. 高解像度と高速化を求め, ハードとソフトが表裏 一体となって発展するとの構図は, 将来においても変 わらないと思われる。

$\mathbf{2 \cdot 1}$ 超音波診断装置 3 種の診断装置の中で, 最 
も人体に対する負荷が小さい装置である.プローブを 接触させて反射波を画像化するため, 高精度の画像を 得にくいとされてきたが, 高速で画像が得られること, 血流のようすをドップラー効果で可視化できることか ら，広く普及している(1)(2). 他の装置に遅れをとった が，三次元画像を取得することが現実的になっており， 高画質三次元画像取得への試みが続けられている(3). また軟組織の弾性特性を測定する装置としての発展性 も期待されている(4).

$2 \cdot 2 \mathrm{X}$ 線診断装置 直接変換型フラットパネル ディテクタにより, 透視撮影においてはデジタル技術 を生かした高画質な動画(5) 得ることができるよう になっている. その点に加え, 近年の主要な展開は, 高速で撮影できる X 線 CT の開発にある(6)(7)．X 線被 爆が最大の欠点である X 線診断装置にとって, 高速 化による被爆量低減は必要命題である。マルチスライ ス CTでは, 8 あるいは 16 さらには 256 の検出器を並 列化し, 毎秒 2 回転で多断面の撮影を行うことが想定 されている. 256 の並列化では, リアルタイムに近い 撮影が可能であり，被爆量低減の観点のみならず，鮮 明な動画を得ることにより，医療への多大な貢献が期 待されている.

$2 \cdot 3$ MRI 装置 患者に負担をかけずに鮮明な三 次元画像を得ることができる装置と考えられてきた が，高速化の展開を行いがたい状況にある．現状でさ らに高速化を図ろうとすれば，高周波による加熱作用， 末梢神経の刺激, 大騒音の 3 点で, 患者に多大な負担 を強いることになると考元られている(8). その限界を 打破するために, パラレルイメージング法が開発され つつある。

\section{3. 画像処 理}

\section{$3 \cdot 1$ シミュレーション支援技術としての現状}

バイオメカニクスにおける画像処理技術のおもな役割 は, 微小間隔で撮像された断面画像から, 三次元幾何 モデルを作成することであった。流体解析では, 固体 解析に比へ，流体境界形状に対する正確度の要求が高 い, そのため, 循環器系の解析においては, 医用デジ タル画像をそのまま用いることははばかられ，なんら かの方法により数值解析に耐えうる滑らかな境界形状 を構築する必要がある。多用されているのは, Marching Cubes 法から表面形状をスムージング化する方 法 ${ }^{(9)}$, 表面構築の際に B-splineなどの関数曲面をは り，滑らかな表面形状を得るとともに血管形状のパラ メー夕の算出を行う手法(10), あるいは三次元位相強調 血管造影(Phase Contrast Angiography：PCA)を用

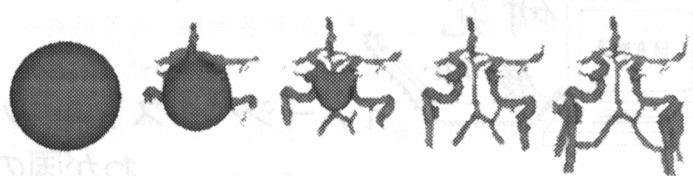

Fig. 1 Evolution of Geodesic Active Contour (GAC) applied on brain vessel

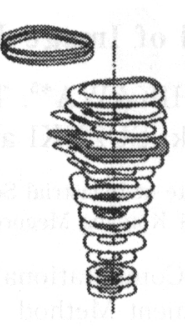

(a)

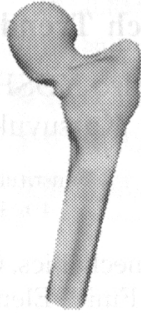

(b)

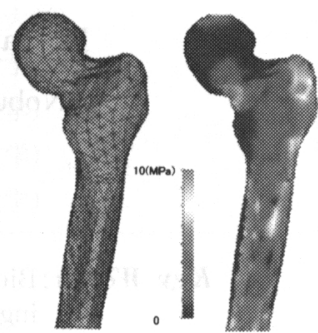

(c)

(d)
Fig. 2 Process of patient oriented modeling and analysis of femur based on X-ray CT images; ( a ) outline of CT images, (b) CAD model, (c) FEM model, and (d) stress distribution

いた MR-PCの画像に対してレベルセット法を共通 基盤として, 血管の領域分割と流れ場の計測を行う手 法(図 1)(11) 等である.

骨格系の解析においては境界形状表現の厳密さに対 する要求は高くない，そこでは，二次元断面画像から 抽出される輸郭線を基にモデルを作成する方法(12)(13) と三次元画像情報を直接用いてボクセルモデルや四面 体モデルを作成する方法 ${ }^{(14) \sim(17)}$ が主に用いられる。 複雑な形状を有する骨のモデルは, X 線 CT 断層像か ら得られる二次元画像内の領域輪郭線の抽出を経て, それらの三次元的な積層により作成される.この過程 において, 図 2 に示すように $\mathrm{CAD} / \mathrm{CAE}$ 技術を援用 することで, 実際に臨床で得られる程度の CT スライ 久間隔の情報量で, 十分な精度のモデル化と力学解析 を行う手法が提案されている(12). 一方, CT 画像の三 次元情報から直接的にボクセル有限要素モデルを作成 する手法(14) は, 三次元画像の画素情報をそのまま用 いて骨の形状を表現するため, モデル作成が簡便であ る.さらに, 同一サイズのボクセル要素を利用するこ とにより, EBE (Element-by-Element)法などの大規 模解析に馴染みやすい, 図 3 は, 大腿骨近位部の X 線 CT スライス画像から構築した約 10 億個の 0.1 $\mathrm{mm}$ サイズのボクセル要素からなるモデルとその応 力解析例(18) であり, 複雑な外形状および内部構造を もつ骨の力学解析には, その威力を発揮する。ささらに, $\mathrm{X}$ 線マイクロ $\mathrm{CT}$ 等に代表される微視構造の計測手 法の発達により, 骨梁構造を詳細に再現した海綿骨の 


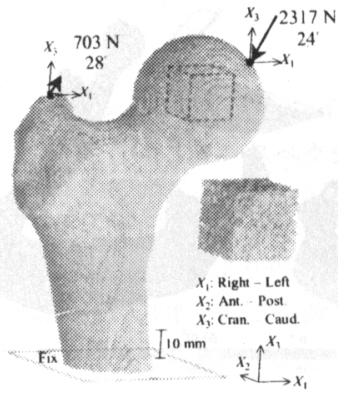

( a )

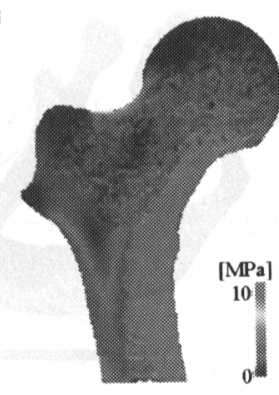

(b)

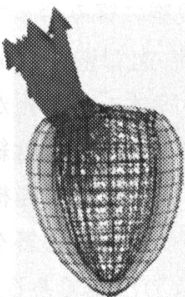

(a)

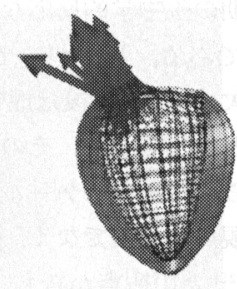

(b)
Fig. 4 Comparison of blood flow simulation between (a) normal and (b) abnormal hearts

Fig. 3 Large-scale voxel modeling and analysis of a proximal femur based on $\mathrm{X}$-ray $\mathrm{CT}$ images; (a) voxel model and (b ) stress distribution

デジタルイメージモデルが作成され，リモデリングに よる骨梁構造変化が定量的に評価されるようになっ た(15). その一方で, ボクセル要素を用いて滑らかな外 形状や骨ーインプラント界面を表現するためには, 非 常に細かな分割が必要となり，計算時間とコストの問 題が生じるため, 臨床への応用においては課題が残さ れる。特に骨とインプラントの界面近傍における摩 擦・接触等の非線形なふるまいの解析への対処が重要 である。そのような問題の場合には，形状表現と解析 要素を別々のボクセルにて表し, 解析精度コントロー ル可能とした, 有限被覆法の適用も一手段であると考 えられる(19).

$3 \cdot 2$ 可視化技術としての展望これまで幾何モ デル作成の役割に加えて, 今後はバイオメカニカルシ ミュレーションを可視化し, 医師や患者の理解を助け るとの役割が重要となると思われる。人工物と異な り, 人体組織は生来的に複雑な三次元形状をしており, 平面的な表現で形状自体を認識することが難しい. そ れにシミュレーションの結果を重畳するわけであり, 関連する力学に必ずしも明るくない医師や患者に情報 を伝えるためには, バーチャルリアリティやアニメー ション技術を駆使した表示方法が必要であると思われ る.

\section{4. 循環系パイオメカニクス}

$4 \cdot 1$ 現状循環系におけるイメージベーストシ ミュレーションの対象は, 心臟血管系と脳血管系に大 別される。心臓血管系は心臓のメカニズムや動脈硬化 や大動脈瘤などの疾患の血行力学的メカ二ズ ム(9)(20) (22), 脳血管については脳循環, あるいは脳動 脈瘤の発生と破裂メカ二ズムの解明(10)(11)(23) を目的と して行われることが多い。これまでは, 心蔵あるいは

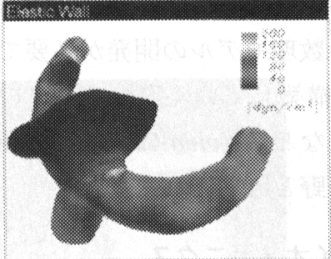

(a) Elastic Wall

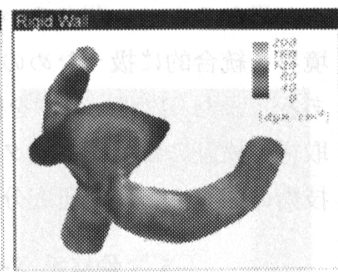

(b) Rigid Wall
Fig. 5 Comparison of effects of walls in the cerebral aneurysm

脳血管の, ある一部の限られた領域の解析が行われる ことが多かったが, 循環系を広範囲で解析する研究, あるいは血流のみならず, 血流-血管壁の連成問題へ と展開が図られている. 一方, 血流のもつ力学的刺激 が細胞などのマイクロレベルに及ぼす影響を数理モデ ル化していくマルチレベル・シミュレーションの研究 も行われている(24)(25).

形状にかかわる幾何学的境界条件とともに, 力学的 境界条件を適切に設定することも解析に不可欠であ る. 循環系は心臓を中心とした閉ループであるので, 動脈血管網を一次元モデル化して,まず各血管内の圧 力波の伝ぱと流速を予測し, その結果と局所血管の画 像情報に基づく実形状モデルを用いて詳細解析を行う との方法論が一般に用いられている(21). また，心臓系 の解析においては, 拍動の影響を陽に取込んだ強連成 解析を行う必要がある. ALE(Aribiraty Lagrangian-Eulerian)による心筋の運動を含めた心臓の拍動 シミュレーション例を図 4 に示す(20). 心蔵と比較し て変形は小さいが, 脳動脈等血管の破裂を考える際に も血管壁の変形を考慮する必要がある. 血管壁の弾性 変形を考慮する場合としない場合で, 脳動脈瘤で発生 するせん断応力の分布は明らかに異なる(図 5) ${ }^{(10)}$.

$4 \cdot 2$ 将来展望 循環系疾患は血管壁が血流によ り機械的刺激, 特に壁面せん断応力を受け, それらの 力学的な刺激と生体 (血管)の直接の相互作用および短 
期〜長期の生物学的反応などが複雑に絡み合って起こ る病気である。したがって, 血流一血管壁の連成解析 は不可欠であり, 今後は血管壁の固体モデル化が重要 な課題となってくる. その際にキーとなるのは細胞レ ベルからのマルチスケール化で, 固体モデルを構築す るとの観点ばかりでなく, 細胞レベルでの応答を評価 する(24)(25) との観点からも，重要な方法論である.

将来的にはこ杖のマルチレベル, マルチフィジッ クスの連成解析を通してヒト全循環系統合シミュレー ションシステムの開発が進められていくと考えられ る. 今後は, 要素で行われている解析を統合的に扱い, また異なるレベル間あるいは異なるフィジックス間の 境界を統合的に扱うための数理モデルの開発が必要で ある.また，数理モデルを構築していく際のデータの 取得や検証のためのデータなど in vivoにおける計測 技術の開発も重要な研究分野と考えられる。

\section{5. 骨格系バイオメカニクス}

$5 ・ 1$ 現状 骨を線形弾性体としてモデル化する ことは, 多くの実際的な解析に対して, 問題ないと考 えられているが，そのミクロ構造から由来する異方性 と不均質性については，十分考慮する必要があると考 えられている(26). 例えば, X 線 CT 画像に基づいて, 形状データのみならず力学的特性の分布を算出するこ とが可能となり, 応力・ひずみ評価の信頼性向上が図 られている(図 6) (27).

骨やインプラントに関しては, 現状でも有限要素解 析の信頼性は高いと考元られており、イメージベース トモデリング手法の整形外科や整科領域における臨床 バイオメカニクス研究への応用が多く試みられてい る. 人工股関節ステムと大腿骨のデジタルモデルを計 算機内において融合することで, ステムの骨髄占拠率 や骨除去体積など臨床上重要な定量的デー夕を評価 し, 同時に応力やひずみ等の力学的評価を行うシステ 厶が開発されている(28)。この手法により, 従来, 二次 元 X 線写真にステムの外形状を表すテンプレートを 重㸚合わせることで行われていたステムの形状適合性 の術前評価を三次元デジタル空間内で行うことが可能 となり, 力学的解析情報を加えたステムの選定に応用 される。

また, CG 技術やロボット制御技術を基礎とする人 工股関節手術の支援システム ${ }^{(29)}$ と融合することによ り，信頼性の高いコンピュータ外科・手術支援の可能 性が期待される。 さらに, 骨とステムとの界面におけ る応力状態をあらかじめ考慮したステムの形状の最適 設計(30) などへの応用も可能となる。

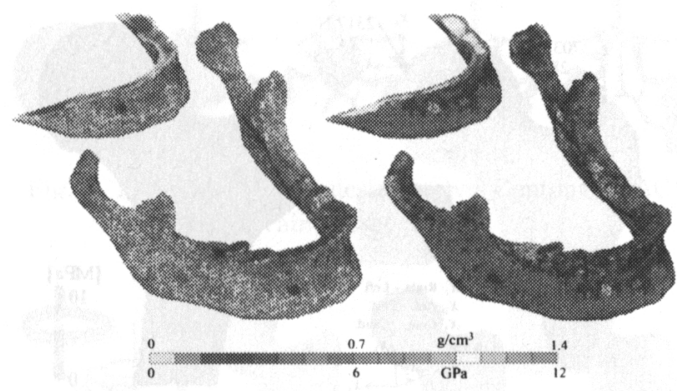

(a) Bone density

(b) Young's modulus

Fig. 6 Distribution of bone density and Young's modulus of human mandible model based on CT images [文献 (27)の図を改変]

$5 \cdot 2$ 将来展望 個体別モデリング技術とそれを 用いた力学解析に基づく骨の力学状態の評価は, 臨床 に扔いて問題となる個々の症例に対して, あるいは， 直接観察や測定が困難な問題に対して, 大変有用であ る。医療画像から得られる形態的な知見のみならず, バイオメカニクス的な検討を加えることにより，臨床 診断や病因の解明，予防において大変役立つ情報を提 供することが可能となる，例えば，計算機内に構築さ れた個体別モデリング手法に基づく計算モデルを用い ることにより，発症の原因となる因子の影響をパラメ トリックに変化させることが可能となり,これが, 実 験的には不可能な問題に対する有用な検証手法となり 得る.

顎関節の代表的な障害の一つである顎関節症の発症 メカニズムに関する検討が進められている ${ }^{(13)}$. バイ オメカニクス解析により, 関節内軟組織の応力状態を 評価し，顎関節症の発症因子の一つと考えられる関節 円板前方転位について, 関節円板の損傷や関節コンポ ーネントの性状変化が及ほすす影響について詳細な検討 が行われている。.また, 大腿骨の頸部骨折の発症機序 を解明すべく，基本となる大腿骨形状の有限要素モデ ルを作成し，これをパラメトリックに変化させること で個体差による骨形状の相違を表現するための手法が 提案されている( ${ }^{(31)}$. この手法を用いて, 大腿骨近位部 の形態的特長を表現する形状パラメータが導入され, それらの変化が頸部骨折発症の危険度に及ほす影響が 検討されている。ささらに,これを用いたヒッププロテ クタの設計指針の検討が進められている。

以上の上うに, 骨のバイオメカニクス研究において, イメージベーストモデリングとそれを用いた力学解析 は，もはや不可欠な基礎技術となっており，特に，整 形外科や歯科領域の臨床で生じるさまざまな力学的問 
題に対して, 今後ますますその活用範囲は広がるもの と考えられる.

\section{6. シミュレーションインテグレイテッド インスペクション}

これまでは，計測はシミュレーションとは独立した 技術であり, 計測により得られた情報をシミュレーシ ヨンに一種の基準として引渡し，シミュレーションの 確度を上昇させるものであると考えられてきた。しか しながら, 生体内部の計測に関しては, 非侵襲あるい は低侵襲にて行うことが前提であるため, 計測の精度 にはおのずと限界がある。その限界を越えた計測を行 うためには, 既往の枠組みにとらわれずに, シミュレ ーションあるいはそれに類する計算技術を積極的に計 測技術の一部に取込む必要があると思われる。画像診 断装置を例にとれぱ, いくら高精度とはいえ生体内部 の情報として得られるのはあくまでも画像であり, 得 たい情報を直接的に示すものではない. シミュレーシ ヨンを融合した，いわばシミュレーションインテグレ イテッドインスペクションとでも呼ぶべき測定方法に より,ょり詳細で正確な力学情報を得ようとの試みが 始まっている。

$6 \cdot 1$ 超音波診断装置による血流計測超音波診 断装置は患者に対する負荷が小さく, また高速で画像 を取得できる利点がある反面, 得られる情報の精度の 点で問題が多いと考えられてきた. その問題点をコン ピュータシミュレーションにより解決できれば, 診断 装置としての価值を飛躍的に増すことになると思われ る. 超音波診断装置による血流計測に関して, スーパ ーコンピュータシステムと一体化された超音波計測融 合シミュレーションシステムが開発されつつあ $る^{(32)}$. 超音波診断装置による血流の計測結果と, 流れ の数值シミュレーション結果の間に逆問題を構成し, 時々刻々の血流状態を正確に再現する。図 7 に示すよ うに, 経食道で挿入されたプローブを用いたカラード プラ法により大動脈の潰瘍部の血流が可視化される. 上流境界での血流速度分布が未知であるので, トライ アルシミュレーションとして, それを一様流として計 算を行う.その結果から得られた速度成分と, 診断画 像から求めた超音波方向の速度成分の差を求め, その 差に応じた体積力を付加するとの方法で, 複雑な血流 構造を再現するシミュレーションを可能とする( ${ }^{(33)}$. この方法によれば, 現在計測不可能な血流の圧力分布, 血管壁上のせん断応力分布などが正確にコンピュータ 上に再現され, より正確な医療診断や治療計画が可能 となると思われる。

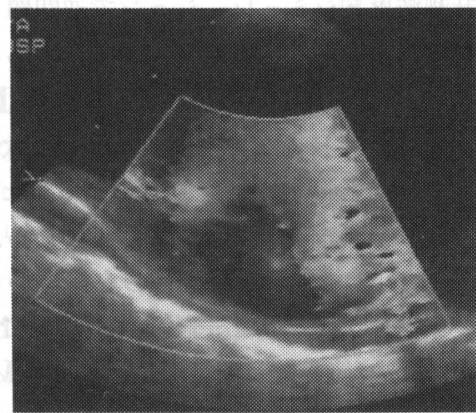

Fig. 7 Measurement-integrated (MI) simulation for blood flow around aneurysm in aorta

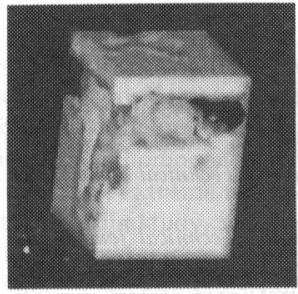

(a) Initial state

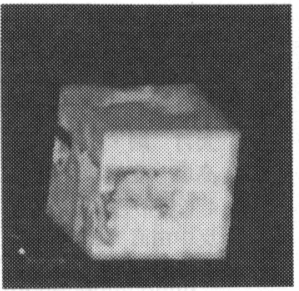

(b) Loaded state
Fig. 8 Voxel models for displacement field identification

6.2 X 線 CT 画像からの変位場同定 固体力学 の基礎となる状態量は, 変位とひずみおよび応力であ る.そのうち, 画像情報から得られるのは, 変位とひ ずみに関する情報である. 力学負荷が与えられたとき の変位場を, X 線 CT 画像を用いて同定する手法が開 発されている(34)(35). 無負荷の状態と負荷を与えられ た状態で, それぞれ X 線 CT 画像を撮像して, 図 8 に 示す二つの三次元ボクセルモデルを構築する.これら ボクセルモデルの同一物質点の間に成り立つ関係を逆 問題構成で同定し変位場が得られる。

\section{7. おわりに}

高性能画像診断装置により，三次元画像を高速かつ 高解像度で得ることが可能となったが, 現在までのと ころ画像はあくまでも画像であり, 得られるのは幾何 学的な情報のみである。疾病の発症に多大な影響を与 えると考えられる力学的情報を得ることが, バイオメ カニクスシミュレーションの目的であり, 確度の高い シミュレーションが要求される.これまでは, シミュ レーションに必要な生体の幾何学モデルの確度を上げ るため, 医療画像を用いることに主眼がおかれてい た.これからは, 解析結果自体の確度が要求され, そ のためには, 計測結果を解析に用いるとの一方通行で 
はなく, 計測結果とシミュレーションで逆問題を構成 し, 真の力学情報を得るとの方向性が必要であろうと 思われる。

高度な計算機科学技術を融合することで, ハードウ エアのみに頼った診断の限界を乗り越えることが, バ イオメカニカルシミュレーションの目的である。機械 設計における CAD 技術は, 平面図の立体視から始ま り, 有限要素法による解析と一体化することで, 生産 活動に不可欠な技術となった. 医療診断においては, 個人差の問題と非侵襲性の制約から, シミュレーショ ンの意義は機械設計以上に重い.その意味で, 計算機 科学技術を融合した診断技術の重要性はますます高ま るものと思われる.

\section{文献}

（1）原 喜芳, 東芝レビュー, 57-2 (2002), 13-16.

(2) 大竹 剛・ほか 4 名, 日立評論, 85-9 (2003), 37-42.

(3) 高坂 登・ほか 4 名, Matsushita Technical Journal, 494 (2003), 291-295.

（4）反中由直 - 橋本雅彦, Matsushita Technical Journal, 494 (2003), 282-289

（5）三浦嘉章・ほか 12 名, 島津評論, 59-3・4 (2003), 141-146.

（6）信太泰雄, 東芝レビュー, 57-2 (2003), 9-12

（7） 信藤康孝, 機誌, 106-1018 (2003), 688-689.

（8）白井嘉行・ほか2 名, 東芝レビュー, 57-2 (2003), 17-20.

（9）渡邊正宏・松澤照男，シミュレーション，22（2003），3438.

（10）鳥井亮・ほか 4 名, 機論, 70-697, A (2004), 1224-1231.

(11) Watanabe, M., ほか 2 名, Lecture Notes in Computer Science, 2488 (2002), 405-412.

(12) 杉森端三・ほか 5 名, 日本臨床バイオメカニクス学会誌, $21(2000), 87-91$.

（13）田中正夫・ほか 4 名, 機論, 69-677, A (2003), 141-147.
(14) Hollister, S. J. and Kikuchi, N., Biotechnol. Bioeng., 437 (1994), 586-596.

（15）安達泰治・ほか 2 名, 機論, 66-648, A (2000), 1640-1647.

(16) 鈴木克幸, 計算工学講演会論文集, 7 (2002), 535-538.

（17）伊能教夫・ほか 3 名, 機論, 68-669, C (2002), 1481-1486.

（18）坪田健一・ほか 3 名, 第 15 回バイオエンジニアリング講 演会, 機講論, 02-35 (2003), 395-396.

（19）鈴木克幸・ほか 3 名，日本造船学会論文集，182（1997）, 595-600.

(20) Watanabe, H., ほか 4 名, JSME Int. J., 45-4, C (2002), 1003-1012.

(21) Liu, H., ほか 6 名, Proc. ASME 2003 Summer Bioen gineering Conference, (2003), 0511-0512.

(22) Nakamura, M., ほか 4 名, JSME Int. J., 44-4, C(2001), 1013-1020.

(23) Oshima, M., ほか 4 名, Comput. Methods Appl. Mech. Engrg., 191 (2001), 661-671.

(24) Tamagawa, M. and Akamatsu, T., JSME Int. J., 42-3, C (1999), 640-647.

(25) Tamagawa, M., ほか 2 名, JSME Int. J., 44 4, C(2001), 1031-1040.

（26）田原大輔・ほか 2 名, 第 15 回バイオエンジニアリング講 演会, 機講論, 02-35 (2003), 77-78.

（27）伊能教夫・ほか 2 名, 機論, 69-677, A (2003), 109-114.

（28）安藤知明・ほか 4 名, 計算工学講演会論文集, 7 (2002), 557-560.

（29）中島義和・ほか3 名, Medical Imaging Technology, 152 (1997), 87-94.

（30）安達泰治・ほか 3 名, 日本臨床バイオメカニクス学会誌, 23 (2002), 405-410

（31）田中英一・山本創太・ほか 4 名, 機論, 70-697, A (2004), 1193-1200.

(32) Hayase, T. and Hayashi, S., J. Fluids Eng., Trans. ASME, 119 (1997), 814-822.

(33) Hayase, T., ほか 5 名, Proc. Mini-Symposium on Advanced Fluid Information: Fusion of EFD and CFD, (2002), 77-85.

(34) Bay, B. K., ほか3 名, Experimental Mechanics, 39-3 (1999), 217-226.

（35）吉川暢宏・ほか 3 名, 機論, 70-697, A (2004), 1284-1291。 